\title{
Excess fluid volume: sociodemographic and clinical analysis in haemodialysis patients
}

\author{
Excesso de volume de líquidos: análise clínica e sociodemográfica em pacientes de hemodiálise
}

El exceso de volumen de líquido: el análisis sociodemográfico y clínico en pacientes en hemodiálisis

\section{Maria Isabel da Conceição Dias Fernandes', Camila de Souza Soares', Jéssica Dantas de Sá Tinôco', Millena Freire Delgado', Maria das Graças Mariano Nunes de Paiva', Marcos Venícios de Oliveira Lopes", Ana Luisa Brandão de Carvalho Lira'}

'Universidade Federal do Rio Grande do Norte, Postgraduate Program in Nursing. Natal, Rio Grande do Norte, Brazil.

"Universidade Federal de Ceará, Department of Nursing. Fortaleza, Ceará, Brazil.

\section{How to cite this article:}

Fernandes MICD, Soares CS, Tinôco JDS, Delgado MF, Paiva MGMN, Lopes MVO, et al. Excess fluid volume: sociodemographic and clinical analysis in haemodialysis patients. Rev Bras Enferm [Internet]. 2017;70(1):11-7.

DOI: http://dx.doi.org/10.1590/0034-7167-2015-0138

Submission: 01-04-2016 Approval: 07-17-2016

\section{ABSTRACT}

Objective: To analyse the defining characteristics and related factors in the nursing diagnosis Excess fluid volume and its relationship to sociodemographic and clinical variables in haemodialysis patients. Method: Cross-sectional study, conducted using a form and physical examination, with a sample of 100 patients, between December 2012 and April 2013 at a university hospital and a dialysis clinic. Results: It was found 10 significant statistical associations between the defining characteristics/ related factors of Excess fluid volume and the sociodemographic and clinical variables. Conclusion: The defining characteristics and related factors of Excess fluid volume could be influenced by sociodemographic and clinical variables in haemodialysis clientele.

Descriptors: Nursing Diagnosis; Renal Dialysis; Body Fluids; Signs and Symptoms; Nursing.

\section{RESUMO}

Objetivo: analisar as características definidoras e fatores relacionados ao diagnóstico de enfermagem excesso de volume de líquidos e sua relação com variáveis clínicas e sociodemográficas em pacientes em hemodiálise. Método: estudo transversal, desenvolvido com a utilização de um formulário e exame físico, com uma amostra de 100 pacientes, entre dezembro 2012 e abril 2013 em um hospital universitário e uma clínica de diálise. Resultados: dez associações estatisticamente significantes foram encontradas entre as características definidoras/fatores relacionadas ao excesso de volume de líquidos e as variáveis clínicas e sociodemográficas. Conclusão: as características definidoras e fatores relacionados ao excesso de volume de líquidos podem ser influenciados por variáveis clínicas e sociodemográficas em pacientes em hemodiálise.

Descritores: Diagnóstico de Enfermagem; Diálise Renal; Líquidos Corporais; Sinais e Sintomas; Enfermagem.

\section{RESUMEN}

Objetivo: analizar las características definitorias y los factores relacionados con el diagnóstico enfermero de exceso de volumen líquido y su relación con variables sociodemográficas y clínicas en pacientes de hemodiálisis. Método: estudio transversal, realizado mediante un formulario y examen físico, con una muestra de 100 pacientes, entre diciembre de 2012 y abril de 2013 en un hospital universitario y una clínica de diálisis. Resultados: se encontraron 10 asociaciones estadísticamente significativas entre las características definitorias, factores relacionados de volumen de exceso de líquido y las variables sociodemográficas y clínicas. Conclusión: las características definitorias y los factores relacionados de exceso de volumen líquido podrían estar influenciados por variables sociodemográficas y clínicas en clientes de hemodiálisis.

Descriptores: Diagnóstico de Enfermería; Diálisis Renal; Líquidos Corporales; Signos y Síntomas; Enfermería. 


\section{INTRODUCTION}

Chronic kidney disease (CKD) is progressive and irreversible kidney damage and is associated with decreased glomerular filtration rate. The filtration and renal regulation failure generates the accumulation of toxic substances in the body, triggering water, electrolyte, acid-base, endocrine and metabolic disorders ${ }^{(1)}$.

Therefore, performing treatments that replace kidney functions is needed. Accordingly, haemodialysis (HD) plays a primary role. At of the end of the year 2012, 3,010,000 patients worldwide had end-stage renal disease. Of these, $70 \%$ underwent haemodialysis ${ }^{(2)}$.

This therapy consists of blood filtration with the aid of a dialysis machine, through a dialyser, in which toxic substances and excess nitrogen liquid are excreted, and the function of the renal glomeruli and tubules is supported ${ }^{(1)}$. Despite the appropriate follow-up, this treatment does not completely replace renal function and causes the accumulation of excreta nitrogen, fluids and electrolytes, which are responsible for signalling the signs and symptoms in this clientele $\mathrm{e}^{(3-4)}$.

Amongst the effects of renal impairment, liquid accumulation is a central problem in these individuals. This excess is the response to the water imbalance between entry and output of the liquids in the organisms, causing complications such as cardiovascular problems ${ }^{(5)}$.

In this context, nursing care needs to directly address the actual customer's needs during haemodialysis. The identification of nursing diagnoses (ND), a step of the nursing process that helps to organise and direct care, translates human responses experienced by the customer in relation to their health condition ${ }^{(6)}$.

The International ND from NANDA International (NANDA-I) "Excess fluid volume" is defined as increased retention of isotonic liquids ${ }^{(7)}$. It comprises 25 defining characteristics and three related factors ${ }^{(7)}$.

Studies with patients submitted to haemodialysis have indicated the high prevalence of this nursing diagnosis ${ }^{(8-9)}$, having a prevalence of $82 \%$ in patients undergoing haemodialysis. Moreover, the following characteristics were significantly associated with this diagnosis: agitation, pulmonary congestion, jugular distension, oedema, altered electrolytes, weight gain, feed intake greater than the debt and adventitious breath sounds ${ }^{(10)}$.

Another study confirmed the above research and suggested that water retention is common in haemodialysis patients and is associated with worse outcomes, including various heart conditions such as tissue ischemia, arrhythmia and sudden cardiac death, in addition to acute pulmonary oedema and hypertension. Hypertension is an important risk factor for cardiovascular disease, which is commonly seen in populations with declining renal function ${ }^{(11-13)}$.

Accordingly, the onset of renal replacement therapy partially decreases the symptoms of failing kidneys; however, high blood pressure levels persist in most patients. The fluid overload due to water retention predisposes patients to hypertension and may clinically manifest itself in various problems, including peripheral oedema ${ }^{(12)}$.

These patients are often immersed in a disadvantaged social class, a problem that may influence non-adherence to treatment and consequently in the presence of water retention. A study on this issue revealed that CKD occurs mainly in poorer regions, with a strong association between low economic development and the availability of therapy ${ }^{(14)}$. Additionally, low-income individuals are more prone to chronic diseases. Therefore, the association between chronic diseases, such as diabetes, hypertension, CKD, and socioeconomic factors demonstrate the importance of health care in disadvantaged groups, which are prevalent in countries where inequalities are evident ${ }^{(15-16)}$.

The main elements of problem-focused nursing diagnoses are the defining characteristics and related factors. The defining characteristics correspond to the signs and symptoms presented by patients, which should be assessed in a clear and precise manner. The related factors are the focus of the nursing intervention ${ }^{(7)}$.

Therefore, recognising the components of Excess fluid volume and associating them to sociodemographic and clinical data of patients submitted to haemodialysis can help nurses planning interventions targeted towards the needs of patients. Accordingly, we aimed to analyse the defining characteristics and related factors to Excess fluid volume and its relationship to sociodemographic and clinical variables in haemodialysis patients.

\section{METHOD}

\section{Ethical aspects}

This study has respected the ethical principles of research and was approved by the Research Ethics Committee and the Presentation Certificate of Appreciation for Ethics. All participants signed a consent form.

\section{Type of study}

This is a cross-sectional study conducted at a university hospital and a dialysis clinic located in a city in Northeast Brazil.

\section{Sample calculation and sample}

The population was composed of individuals with CKD on haemodialysis in the places where the data were collected. The sample was calculated from the formula $\mathrm{n}=\mathrm{Za}$ 2.Se.(1Se)/L2.P $\mathrm{P}^{(17)}$ according to the following parameters: 95\% confidence level, conjectured sensitivity of the most important bookmarks of $85 \%$, one-half of the length of the confidence interval constructed of $10 \%$ and a proportion of $50 \%$ of adults presenting with the diagnosis under study. Therefore, the final sample consisted of 100 individuals.

\section{Sample selection}

The selection of the patients was by convenience, and participants were chosen consecutively. Inclusion criteria were the following: patient with CKD; on haemodialysis; at the time of data collection, in the first hour of haemodialysis, and aged 18 years or older. The exclusion criteria were the following: physical and mental conditions that impaired the collection of all instrument items.

\section{Collection and instrument data}

The data collection instrument was a form developed for the study objectives from existing elements in the ND "Excess fluid 
volume" from NANDA-I. The form was organised as follows: demographic data, clinical history, general physical examination and sections with the body data and laboratory tests. The laboratory data were recorded from the patients' files.

We conducted training with eight nursing course graduate students who conducted the data collection. The training was composed of ten hours and was divided into two meetings that addressed the following approaches: theme of the study, objectives and research method; ND "Excess fluid volume"; operational definitions of the defining characteristics; and review of the diagnostic methods of the physical examination. The course was taught by a nurse and coordinated by an adviser professor to the project.

Data were collected during December 2012 to April 2013. Data were collected during the first hour of a haemodialysis session to provide more reliable measurement of body fluids, preventing changes in its volume.

\section{Statistical analysis}

To organise the data, a computerised database in Excel was developed and contained the defining characteristics and related factors of Excess fluid volume and clinical and sociodemographic data. Data analysis was conducted with IBM SPSS version 20.0 Statistic for Windows and included a descriptive and inferential analysis. In the descriptive analysis, we used measures of central tendency and dispersion, including the Kolmogorov-Smirnov test for normality of the data. For descriptive analysis of quantitative variables, we calculated the mean and standard deviation (SD). In the inferential analysis, we used Pearson's chi-square test, Fisher exact test and the Mann-Whitney test to correlate the defining characteristics, related factors and sociodemographic and clinical data. We adopted a statistical significance level of $5 \%(p<0.05)$.

\section{RESULTS}

Concerning sociodemographic data, 52\% were female, $57 \%$ had a partner and mean age was 51.1 years (SD 16.5). In regard to family income, the median was two minimum wages, varying from zero to 15 wages (considered $R \$ 678.00$ as the Brazilian minimum wage during the survey period). Regarding education, the median was 6.5 years of schooling (SD 5.0).

Regarding the clinical data, patients had a median of 48.0 months with renal disease (SD 78.9), and the average number of months on haemodialysis was 28.0 (SD 53.2). The percentages of subjects with diabetes and hypertension were $81 \%$ and $30 \%$, respectively.

We identified 23 defining characteristics, which were the following: azotemia (100\%), decreased hematocrit (96\%), electrolyte imbalance $(88 \%)$, intake exceeds output $(88 \%)$, anxiety $(85 \%)$, edema $(81 \%)$, decreased hemoglobin $(73 \%)$, oliguria $(63 \%)$, blood pressure changes (52\%), increased central venous pressure $(47 \%)$, positive hepatojugular reflex $(46 \%)$, restlessness $(44 \%)$, pulmonary congestion $(42 \%)$, weight gain over short period of time $(42 \%)$, adventitious breath sounds $(40 \%)$, jugular vein distension $(38 \%)$, orthopnea $(30 \%)$, dyspnea $(25 \%)$, change in mental status (19\%), pleural effusion (15\%), anasarca $(8 \%)$, changes in respiratory pattern $(4 \%)$ and S3 heart sound ( $2 \%)$. Related factors included: compromised regulatory mechanism $(100 \%)$, excess sodium intake $(100 \%)$ and excess fluid intake $(88 \%)$.

These associations are shown in Table 1. The hegemonic presence of the defining characteristic azotemia prevented the use of statistical association tests because it had a frequency of $100 \%$.

Table 1 - Associations between the defining characteristics of nursing diagnosis "Excess fluid volume" and sociodemographic and clinical data of patients with Chronic kidney disease undergoing hemodialysis, Natal, Rio Grande do Norte, Brazil, 2014

\begin{tabular}{|c|c|c|c|c|c|c|c|c|c|}
\hline Defining characteristics & Sex & Age & $\begin{array}{c}\text { Marital } \\
\text { status }\end{array}$ & $\begin{array}{c}\text { Years of } \\
\text { study }\end{array}$ & $\begin{array}{l}\text { Family } \\
\text { income }\end{array}$ & Diabetes & Hypertension & $\begin{array}{l}\text { Chronic } \\
\text { kidney } \\
\text { disease } \\
\text { months }\end{array}$ & $\begin{array}{l}\text { Months of } \\
\text { treatment }\end{array}$ \\
\hline Restlessness & ${ }^{\mathrm{a}} 0.652$ & ${ }^{c} 0.649$ & a $0.039 *$ & ${ }^{\mathrm{c}} 0.385$ & ${ }^{\mathrm{c}} 0.469$ & ${ }^{\mathrm{a}} 0.853$ & ${ }^{\mathrm{a}} 0.725$ & ${ }^{\mathrm{c}} 0.829$ & ${ }^{\mathrm{c}} 0.402$ \\
\hline Anasarca & ${ }^{\mathrm{b}} 0.717$ & ${ }^{c} 0.255$ & b 0.072 & ${ }^{\mathrm{c}} 0.413$ & ${ }^{\mathrm{c}} 0.430$ & ${ }^{\mathrm{b}} 0.374$ & ${ }^{\mathrm{b}} 0.694$ & ${ }^{\mathrm{c}} 0.468$ & ${ }^{\mathrm{c}} 0.401$ \\
\hline Anxiety & ${ }^{\mathrm{a}} 0.117$ & ${ }^{c} 0.101$ & ${ }^{\mathrm{a}} 0.412$ & ${ }^{\mathrm{c}} 0.880$ & ${ }^{c} 0.174$ & b1.000 & ${ }^{\mathrm{b}} 0.372$ & ${ }^{\mathrm{c}} 0.368$ & ${ }^{\mathrm{c}} 0.326$ \\
\hline Azotemia & - & - & - & - & - & - & - & - & - \\
\hline Pulmonary congestion & ${ }^{\mathrm{a}} 0.948$ & ${ }^{c} 0.627$ & ${ }^{\mathrm{a}} 0.004 *$ & ${ }^{\mathrm{c}} 0.117$ & ${ }^{c} 0.269$ & ${ }^{\mathrm{a}} 0.598$ & ${ }^{\mathrm{a}} 0.860$ & ${ }^{\mathrm{c}} 0.983$ & ${ }^{c} 0.520$ \\
\hline Pleural effusion & ${ }^{\mathrm{a}} 0.501$ & - & ${ }^{\mathrm{a}} 0.412$ & - & - & b0.291 & b0.766 & - & - \\
\hline Dyspnea & ${ }^{\mathrm{a}} 0.644$ & ${ }^{c} 0.417$ & ${ }^{\mathrm{a}} 0.294$ & ${ }^{\mathrm{c}} 0.087$ & ${ }^{c} 0.486$ & ${ }^{\mathrm{b}} 0.775$ & b0.801 & ${ }^{\mathrm{c}} 0.446$ & ${ }^{c} 0.612$ \\
\hline Jugular vein distension & ${ }^{\mathrm{a}} 0.255$ & ${ }^{c} 0.972$ & ${ }^{\mathrm{a}} 0.268$ & ${ }^{c} 0.299$ & ${ }^{\mathrm{c}} 0.086$ & ${ }^{\mathrm{a}} 0.047 *$ & ${ }^{\mathrm{a}} 0.048^{*}$ & ${ }^{c} 0.243$ & ${ }^{c} 0.342$ \\
\hline Edema & ${ }^{\mathrm{a}} 0.653$ & ${ }^{\mathrm{c}} 0.683$ & ${ }^{\mathrm{a}} 0.346$ & ${ }^{c} 0.324$ & ${ }^{\mathrm{c}} 0.281$ & ${ }^{\mathrm{b}} 0.754$ & ${ }^{\mathrm{a}} 0.344$ & ${ }^{\mathrm{c}} 0.185$ & ${ }^{c} 0.535$ \\
\hline Electrolyte imbalance & ${ }^{\mathrm{a}} 0.445$ & ${ }^{\mathrm{c}} 0.664$ & ${ }^{\mathrm{a}} 0.602$ & ${ }^{\mathrm{c}} 0.475$ & ${ }^{\mathrm{c}} 0.897$ & b 0.694 & ${ }^{\mathrm{b}} 1.000$ & ${ }^{c} 0.694$ & ${ }^{\mathrm{c}} 0.770$ \\
\hline Weight gain over short period of time & ${ }^{\mathrm{a}} 0.456$ & ${ }^{\mathrm{c}} 0.039 *$ & ${ }^{\mathrm{a}} 0.097$ & ${ }^{c} 0.645$ & c0.895 & ${ }^{\mathrm{a}} 0.613$ & ${ }^{\mathrm{a}} 0.860$ & ${ }^{c} 0.372$ & ${ }^{\mathrm{c}} 0.604$ \\
\hline Decreased haematocrit & ${ }^{\mathrm{b}} 0.619$ & ${ }^{\mathrm{c}} 0.090$ & b1.000 & ${ }^{\mathrm{c}} 0.806$ & ${ }^{\mathrm{c}} 0.398$ & b1.000 & b1.000 & ${ }^{\mathrm{c}} 0.653$ & ${ }^{\mathrm{c}} 0.087$ \\
\hline
\end{tabular}




\begin{tabular}{|c|c|c|c|c|c|c|c|c|c|}
\hline Defining characteristics & Sex & Age & $\begin{array}{c}\text { Marital } \\
\text { status }\end{array}$ & $\begin{array}{c}\text { Years of } \\
\text { study }\end{array}$ & $\begin{array}{l}\text { Family } \\
\text { income }\end{array}$ & Diabetes & Hypertension & $\begin{array}{l}\text { Chronic } \\
\text { kidney } \\
\text { disease } \\
\text { months }\end{array}$ & $\begin{array}{l}\text { Months of } \\
\text { treatment }\end{array}$ \\
\hline Decreased haemoglobin & ${ }^{\mathrm{a}} 0.000 *$ & ${ }^{\mathrm{c}} 0.527$ & ${ }^{\mathrm{a}} 0.527$ & ${ }^{\mathrm{c}} 0.271$ & ${ }^{\circ} 0.162$ & ${ }^{\mathrm{a}} 0.617$ & ${ }^{\mathrm{a}} 0.961$ & ${ }^{\mathrm{c}} 0.225$ & ${ }^{\mathrm{c}} 0.390$ \\
\hline Intake exceeds output & ${ }^{\mathrm{a}} 0.882$ & ${ }^{\mathrm{c}} 0.567$ & ${ }^{\mathrm{a}} 0.471$ & ${ }^{\mathrm{c}} 0.364$ & ${ }^{\mathrm{c}} 0.259$ & b1.000 & ${ }^{\mathrm{a}} 1.000$ & ${ }^{c} 0.052$ & ${ }^{\mathrm{c}} 0.001 *$ \\
\hline Change in mental status & ${ }^{\mathrm{a}} 0.951$ & ${ }^{\mathrm{c}} 0.538$ & ${ }^{\mathrm{a}} 0.669$ & ${ }^{\mathrm{c}} 0.614$ & ${ }^{\mathrm{c}} 0.537$ & bo 0.516 & ${ }^{\mathrm{a}} 0.697$ & ${ }^{\mathrm{c}} 0.328$ & ${ }^{\mathrm{c}} 0.243$ \\
\hline Blood pressure changes & ${ }^{\mathrm{a}} 0.047^{*}$ & ${ }^{\mathrm{c}} 0.223$ & ${ }^{\mathrm{a}} 0.796$ & ${ }^{\mathrm{c}} 0.421$ & ${ }^{\mathrm{c}} 0.431$ & ${ }^{\mathrm{a}} 0.337$ & ${ }^{\mathrm{a}} 0.861$ & ${ }^{c} 0.557$ & ${ }^{\mathrm{c}} 0.250$ \\
\hline Changes in respiratory pattern & ${ }^{\mathrm{b}} 0.619$ & ${ }^{c} 0.939$ & b0.632 & ${ }^{\mathrm{c}} 0.123$ & ${ }^{\mathrm{c}} 0.032 *$ & ${ }^{\mathrm{b}} 0.576$ & ${ }^{\mathrm{b}} 0.313$ & ${ }^{\mathrm{c}} 0.885$ & ${ }^{\mathrm{c}} 0.513$ \\
\hline Oliguria & ${ }^{\mathrm{a}} 0.353$ & ${ }^{\mathrm{c}} 0.405$ & $\mathrm{a} 0.970$ & ${ }^{\mathrm{c}} 0.841$ & ${ }^{c} 0.541$ & ${ }^{\mathrm{a}} 0.298$ & ${ }^{\mathrm{a}} 0.390$ & ${ }^{\mathrm{c}} 0.035^{*}$ & ${ }^{\circ} 0.000 *$ \\
\hline Orthopnea & ${ }^{\mathrm{a}} 0.541$ & ${ }^{\mathrm{c}} 0.261$ & ${ }^{\mathrm{a}} 0.692$ & ${ }^{\mathrm{c}} 0.107$ & ${ }^{\mathrm{c}} 0.395$ & ${ }^{\mathrm{a}} 0.867$ & ${ }^{\mathrm{a}} 0.341$ & ${ }^{c} 0.783$ & ${ }^{c} 0.401$ \\
\hline Increased central venous pressure & ${ }^{\mathrm{a}} 0.564$ & ${ }^{\mathrm{c}} 0.123$ & ${ }^{\mathrm{a}} 0.469$ & ${ }^{\mathrm{c}} 0.138$ & ${ }^{c} 0.411$ & ${ }^{\mathrm{a}} 0.585$ & ${ }^{\mathrm{a}} 0.359$ & ${ }^{\mathrm{c}} 0.912$ & ${ }^{\mathrm{c}} 0.338$ \\
\hline Positive hepatojugular reflex & ${ }^{\mathrm{a}} 0.664$ & ${ }^{\mathrm{c}} 0.645$ & a 0.929 & ${ }^{\mathrm{c}} 0.684$ & ${ }^{c} 0.645$ & ${ }^{\mathrm{a}} 0.894$ & ${ }^{\mathrm{a}} 0.220$ & ${ }^{\mathrm{c}} 0.434$ & ${ }^{\mathrm{c}} 0.819$ \\
\hline Adventitious breath sounds & ${ }^{\mathrm{a}} 0.935$ & ${ }^{\mathrm{c}} 0.437$ & ${ }^{\mathrm{a}} 0.011 *$ & ${ }^{\mathrm{c}} 0.221$ & ${ }^{\mathrm{c}} 0.380$ & ${ }^{\mathrm{a}} 0.466$ & ${ }^{\mathrm{a}} 0.656$ & ${ }^{\mathrm{c}} 0.830$ & ${ }^{\mathrm{c}} 0.659$ \\
\hline S3 heart sound & b1.000 & ${ }^{\mathrm{c}} 0.138$ & b1.000 & ${ }^{c} 0.481$ & ${ }^{\mathrm{c}} 0.912$ & b1.000 & ${ }^{\mathrm{b}} 1.000$ & ${ }^{c} 0.204$ & ${ }^{c} 0.253$ \\
\hline
\end{tabular}

Note: * Variables that showed significant association; a Chi-square test; b Fisher's exact test; c Mann-Whitney test. - Variables frequently $100 \%$.

Table 2 - Associations between related factors of the nursing diagnosis "Excess fluid volume" and sociodemographic and clinical data of patients with chronic kidney disease undergoing haemodialysis, Natal, Rio Grande do Norte, Brazil, 2014

\begin{tabular}{|c|c|c|c|c|c|c|c|c|c|}
\hline Related factors & Sex & Age & $\begin{array}{c}\text { Marital } \\
\text { status }\end{array}$ & $\begin{array}{l}\text { Years of } \\
\text { study }\end{array}$ & $\begin{array}{l}\text { Family } \\
\text { income }\end{array}$ & Diabetes & Hypertension & $\begin{array}{l}\text { Chronic kidney } \\
\text { disease months }\end{array}$ & $\begin{array}{l}\text { Months of } \\
\text { treatment }\end{array}$ \\
\hline Excess fluid intake & ${ }^{\mathrm{a}} 0.882$ & ${ }^{\circ} 0.567$ & ${ }^{\mathrm{a}} 0.471$ & ${ }^{\mathrm{c}} 0.364$ & ${ }^{\mathrm{c}} 0.259$ & b1.000 & b1.000 & ${ }^{\mathrm{c}} 0.052$ & ${ }^{c} 0.001 *$ \\
\hline Excess sodium intake & - & - & - & - & - & - & - & - & - \\
\hline $\begin{array}{l}\text { Compromised } \\
\text { regulatory mechanism }\end{array}$ & - & - & - & - & - & - & - & - & - \\
\hline
\end{tabular}

Note: * Variables that showed significant association; a Chi-square test; b Fisher's exact test; c Mann-Whitney test. - Variables frequently $100 \%$.

The defining characteristics that showed significant association with sociodemographic and clinical variables were the following: restlessness and marital status; Pulmonary congestion and marital status; jugular vein distension and diabetes and hypertension; weight gain over short period of time and age; decreased hemoglobin and sex; intake exceeds output and months of treatment; blood pressure changes and sex; changes in respiratory pattern and family income; oliguria and months of CKD and months of treatment; adventitious breath sounds and marital status.

The Table 2 present the association between the related factors of this ND and sociodemographic and clinical data. . Due to the hegemonic presence of the related factors "excess sodium intake" and "compromised regulatory mechanism", it was impossible to perform statistical tests of association because they had a frequency of $100 \%$.

The related factor that was significantly associated with the sociodemographic and clinical variables was Excess fluid intake and months of treatment.

\section{DISCUSSION}

The nursing diagnosis "Excess fluid volume" is an important human response in haemodialysis patients. Excessive accumulation of liquids is presented as a complicating factor of $\mathrm{CKD}^{(5-18)}$. Studies have emphasised the importance of recognising Excess fluid volume in this clientele, indicating it is an independent marker of the effect of interventions ${ }^{(5)}$.

Therefore, the identification of the defining characteristics of the diagnosis "Excess fluid volume" in this population is vital to understand the diagnostic inference. According to the data obtained in this study, we identified azotemia in $100 \%$ of the sample. This characteristic is defined as the increased concentration of urea and additional nitrogenous wastes in the blood ${ }^{(1)}$. According to the literature, although the azotemia has been identified in all patients in the sample, this symptom can be explained physiologically in some patients with renal impairment, regardless of fluid accumulation in the body ${ }^{(10)}$.

Amongst the risk factors that occurred in $100 \%$ of the sample, the most relevant factors were "compromised regulatory mechanism" and "excessive sodium intake". The prevalence of compromised regulatory mechanisms may be due to the changes in renal regulation that chronic renal patients experience ${ }^{(1)}$.

The occurrence of excessive sodium intake in chronic renal disease is due to a dietary intake of sodium higher than the recommended consumption, compared to sodium restrictions imposed by the disease and treatment. Studies have indicated the necessity of using specific amounts in this population because its excess can be related to increased blood pressure, weight gain in a short period and increased mortality in haemodialysis clientele ${ }^{(19)}$. Therefore, nursing should conduct 
health education and promote following the prescribed diet.

The defining characteristics that were significantly associated with sociodemographic and clinical data included "restlessness", "pulmonary congestion" and "adventitious breath sounds", which were significantly associated with marital status. The presence of restlessness in these patients should be observed by the nurse and confirmed by the patient. This symptom can be detected through behavioural changes and can be exemplified by irritability, mood swings, agitation and impatience. Restlessness may occur due to altered electrolytes, especially potassium, in excess fluids ${ }^{(20)}$. Another study demonstrated that restlessness may also be related to the greater amount of toxins in the body in end-stage renal disease $\mathrm{e}^{(21)}$.

The association of this characteristic to marital status may be because people with a marital relationship have greater financial and household management concerns. Because most of the sample had a partner, the restlessness that occurred due to changes in electrolytes was another concern. Therefore, nurses must establish friendly communication and a positive environment to support these patients.

Adventitious breath sounds can be evaluated at the end of inspiration and / or expiration and are more audible in the lung bases ${ }^{(20)}$. Studies have asserted that respiratory changes are commonly identified in haemodialysis clientele, indicating the need for greater attention to this characteristic, which reflects the presence of dyspnoea. Dyspnoea is reduced after a haemodialysis session due to alkalinisation of fluids after haemodialysis. Hyperventilation that occurs before haemodialysis is explained by metabolic acidosis due to accumulation of toxins in the blood $^{(22)}$.

The characteristic changes in respiratory patterns also showed a significant association with family income. The presence of respiratory characteristics was related to the fluid accumulation in the lungs and was caused by blood urea, hypoalbuminemia and / or excess fluid volume in haemodialysis clientele ${ }^{(23)}$. Family income, particularly low income, may predispose the difficulty in properly following the prescribed treatment regimen, which may explain the respiratory changes. Therefore, nursing should consider this information and direct actions according to the financial status of the patient.

The distension of the jugular vein was associated with diabetes and hypertension. Cardiovascular manifestations are commonly identified in chronic renal patients, and hypertension is related to the retention of sodium and fluid or the activation of the renin-angiotensin-aldosterone system in this population ${ }^{(24)}$. In addition to hypertension, jugular venous distension is an important sign of cardiovascular complications due to kidney failure ${ }^{(1)}$.

In another study, the association of cardiovascular events with renal patients was shown to increase mortality rate. Therefore, clinical protocols should be created to prioritise glycaemic control, blood pressure control and lipid control in patients who have heart problems and diabetic patients undergoing haemodialysis ${ }^{(25-26)}$.

Additionally, blood pressure changes were significantly associated with the variable sex. The sample was predominantly female in this study. Studies have indicated that the occurrence of cardiovascular events is more common in women than men ${ }^{(25)}$.
Therefore, nursing should provide interventions for the prevention of cardiovascular events associated with CKD, and especially fluid accumulation, to these patients, particularly women.

Weight gain during a short period of time was significantly associated with the age variable. An increase in weight by more than 1 kilogram / day suggests fluid retention ${ }^{(20)}$. A study showed a significant association between age and weight gain and identified an average age of 59 years ${ }^{(27)}$, which is consistent with this study.

Decreased haemoglobin was significantly associated with sex. In this study, $52 \%$ of the sample was female. Haemoglobin was decreased in this sample because of declining renal function due to lower production of erythropoietin in the kidneys, poor survival and increase of toxins in the blood responsible for causing haemolysis in red blood cells ${ }^{(28)}$. The normal values for haemoglobin are lower in women compared to men (13.5 to $18 \mathrm{~g} / \mathrm{dl}$ in men and 11.5 to $16.4 \mathrm{~g} / \mathrm{dl}$ in women) ${ }^{(20)}$, which explains the observed association. Accordingly, most haemodialysis patients receive drugs that aim to restore the decreased erythropoietin in the body; therefore, adherence to the treatment regimen is important.

The defining characteristic "intake exceeds output" and the related factor "excess fluid intake" were significantly associated with the variable "months of treatment". "Intake exceeds output" indicates that the intake of a quantity of liquid in the body is more than the amount eliminated ${ }^{(20)}$.

A study found that adherence to diet control and fluid intake has no relationship with psychosocial predictors and the perception of health but is related to a set of factors that can influence patient compliance in the control of fluid intake, and the best indicators are not being recognised to predict this behaviour ${ }^{(29)}$. However, a restricted diet can promote distortions in its proper fulfilment.

The variables "months of treatment" and "CKD months" were significantly associated with oliguria. This characteristic is defined as urinary output less than $400 \mathrm{ml}$ in 24 hours $^{(1)}$. A study indicated that this characteristic is an indication of poor prognosis and suggested that Excess fluid volume is a predictor for increased mortality of these clients ${ }^{(30)}$. The duration of CKD and treatment indicates the presence of complications related to progression of renal disease, including oliguria.

Therefore, nurses should educate patients to minimise the presence of the defining characteristics and prevent the related factors from triggering Excess fluid volume. The sociodemographic and clinical data should also be considered to achieve better results, particularly in regard to dietary and medication adherence in haemodialysis patients.

A limitation identified in this study was the focus on the population undergoing haemodialysis; we did not consider additional populations. Furthermore, the lack of relevant scientific literature that confirms or denies the associations identified in this study was also considered a limitation.

\section{CONCLUSION}

Based on the results identified in this study, it was concluded that the defining characteristics and related factors of 
Excess fluid volume could be influenced by sociodemographic and clinical variables in patients undergoing haemodialysis.

Variables that showed significant associations were the following: restlessness and marital status; pulmonary congestion and marital status; jugular vein distension with diabetes and hypertension; weight gain over short period of time and age; decreased hemoglobin and sex; intake exceeds output and months of treatment; blood pressure changes and sex; changes in respiratory pattern and family income; oliguria and months of CKD and treatment; adventitious breath sounds and marital status; excess fluid intake and months of treatment.

The identified associations can help direct nursing care for Excess fluid volume, and the sociodemographic and clinical factors that may prevent positive results in this population should be considered. Therefore, knowledge of these associations should influence the care plan development for these patients and address the needs and social reality of this population.

\section{REFERENCES}

1. Hinkle JL, Cheever KH. Brunner \& Suddarth's Textbook of Medical-Surgical Nursing. 11th ed. Philadelphia: Lippincott Williams \& Wilkins; 2013.

2. Fresenius Medical Care AG \& Co. ESRD Patients in 2012 A Global Perspective. Fresenius Medical Care, Deutschland. 2012.

3. Kalantar-Zadeh K, Regidor DL, Kovesdy CP, Wyck DV, Bunnapradist S, Horwich TB, et al. Fluid retention is associated with cardiovascular mortality in patients undergoing long-term hemodialysis. Circulation [Internet]. 2009[cited 2016 Mar 18];119(5):671-9. Available from: http://circ.ahajournals.org/content/119/5/671.long

4. Guyton AC, Hall JE. Textbook of Medical Physiology. 12th ed. Philadelphia: Elsevier; 2011.

5. Antlanger $M$, Hecking $M$, Haidinger $M$, Werzowa J, Kovarik JJ, Paul G. Fluid overload in hemodialysis patients: a cross-sectional study to determine its association with cardiac biomarkers and nutritional status. BMC Nephrology [Internet]. 2013[cited 2016 Mar 18];14:26676. Available from: http://bmcnephrol.biomedcentral. com/articles/10.1186/1471-2369-14-266

6. Garcia TR, Nobrega MML. [Nursing Process: from theory to the practice of care and research]. Esc Anna Nery Rev Enferm [Internet]. 2009[cited 2016 Mar 18];13(1):188-93. Available from: http://www.scielo.br/ pdf/ean/v13n1/v13n1a26.pdf Portuguese.

7. Herdman TH. NANDA International nursing diagnoses: definitions and classification, 2012-2014. Oxford: Wiley Blackwell; 2012.

8. Costa AGS, Santos RMB, Vitor AF, Araujo TL. Nursing diagnosis of patients in treatment of hemodialysis in teaching hospital. Rev Enferm UFPE [Internet]. 2010[cited 2016 Mar 18];4(3):1477-83. Available from: http:// www.revista.ufpe.br/revistaenfermagem/index.php/ revista/article/viewArticle/1047

9. Frazão CM, Medeiros AB, Silva FB, Sá JD, Lira AL. Nursing diagnoses in chronic renal failure patients on hemodialysis. Acta Paul Enferm[Internet]. 2014[cited 2016 Mar 18];27(1):40-3. Available from: http://www.scielo. br/pdf/ape/v27n1/0103-2100-ape-27-01-00040.pdf

10. Fernandes MICD, Medeiros ABA, Macedo BMM, Vitorino ABF, Lopes MVO, Lira ALBC. Prevalence of nursing diagnosis of fluid volume excess in patients undergoing hemodialysis. Rev Esc Enferm USP[Internet]. 2014[cited 2016 Mar 18];48(3):446-53. Available from: http://www.scielo.br/pdf/reeusp/v48n3/0080-6234reeusp-48-03-446.pdf

11. Choi SH, Shin DS, Jung ES, Kim AJ, Park H, Sung J. Prognostic implication of interdyalitic fluid retention during the beginning period in incident hemodialysis patients. Tohoku J Exp Med[Internet]. 2012[cited 2016 Mar 18];226(2):109-15. Available from: https://www. jstage.jst.go.jp/article/tjem/226/2/226_2_109/_article

12. Ferreira-Filho SR, Machado GR, Ferreira VC, Rodrigues CFMA, Moraes TP, Divino-Filho C. Back to Basics: Pitting Edema and the Optimization of Hypertension Treatment in Incident Peritoneal Dialysis Patients (BRAZPD). PLos ONE[Internet]. 2012[cited 2016 Mar 18];7(5):e36758. Available from: http://journals.plos. org/plosone/article?id = 10.1371/journal . pone. 0036758

13. Halle MP, Hertig A, Kengne AP, Ashuntantang G, Rondeau $E$, Ridel C. Acute pulmonary edema in chronic dialysis patients admitted into an intensive care unit. Nephrol Dial Transplant[Internet]. 2012[cited 2016 Mar 18];27(2):603-7. Available from: http://ndt.oxfordjournals.org/content/27/2/603.long

14. Jha V, Garcia-Garcia G, Iseki K, Li Z, Naicker S, Plattner B, et al. Chronic kidney disease: global dimension and perspectives. Lancet[Internet]. 2013[cited 2016 Mar 18];382(9888):260-72. Available from: http://www.thelancet.com/journals/lancet/article/ PIIS0140-6736(13)60687-X/abstract

15. Cherchiglia ML, Machado EL, Szuster DAC, Andrade ELG, Acúrcio FA, Caiaffa WT, et al. Epidemiological profile of patients on renal replacement therapy in Brazil, 2000-2004. Rev Saúde Pública[Internet]. 2010[cited 2016 Mar 18];44(4):639-49. Available from: http:// www.scielo.br/pdf/rsp/v44n4/en_07.pdf

16. Vasconcelos CR, Dutra DA, Oliveira EM, Fernandes $S$. Socioeconomic profile and clinical of a group in diabetes treatment hemodialysis in Curitiba. Rev UNIANDRADE. 2013;14:183-200.

17. Zhou XH, Obuchowski NA, Mcclish DK. Statistical methods in diagnostic medicine. 2nd ed. New York: Wiley \& Sons; 2002.

18. Tsai $Y$, Tsai J, Chen S, Chiu Y, Hwang S, Hung C, et al. Association of fluid overload with kidney disease progression in advanced CKD: a prospective cohort study. Am J Kidney Dis[Internet]. 2014[cited 2016 Mar 18];63(1):68-75. Available from: http://www.ajkd.org/ 
article/S0272-6386(13)00987-6/abstract

19. Causland FR, Waikar SS, Brunelli SM. The relevance of dietary sodium in hemodialysis. Nephrol Dial Transplant[Internet]. 2013[cited 2016 Mar 18];28(4):797-802. Available from: https://www.ncbi.nlm.nih.gov/pmc/articles/PMC3716331/.

20. Boery RNSO, Guimarães HCQCP, Barros ALBL. [Operational definitions of the defining characterístics of the nursing diagnosis Fluid Volume Excess]. Acta Paul Enferm[Internet]. 2005[cited 2016 Mar 18];18(2):197-202. Available from: http://www.scielo.br/pdf/ape/v18n2/a13v18n2.pdf Portuguese.

21. Douglas C, Murtagh FEM, Chambers EJ, Howse M, Ellershaw J. Symptom management for the adult patient dying with advanced chronic kidney disease: a review of the literature and development of evidence-based guidelines by a United Kingdom Expert Consensus Group. Pallia Med[Internet]. 2009[cited 2016 Mar 18];23:103-10. Available from: http:// pmj.sagepub.com/content/23/2/103.long

22. Palamidas AF, Gennimata S, Karakontaki F, Kaltsakas G, Papantoniou I, Koutsoukou A, et al. Impact of hemodialysis on dyspnea and lung function in end stage kidney disease patients. BioMed Res Int[Internet]. 2014[cited 2016 Mar 18];1-10. Available from: https://www. hindawi.com/journals/bmri/2014/212751/.

23. Riella MC. Principles of Nephrology and electrolyte disturbances. 5th ed. Rio de Janeiro: Guanabara Koogan; 2010.

24. Buren PNV, Inrig JK. Hypertension and hemodialysis: pathophysiology and outcomes in adult and pediatric populations. Pediatr Nephrol[Internet]. 2012[cited 2016 Mar 18];27(3):339-50. Available from: http://link. springer.com/article/10.1007\%2Fs00467-011-1775-3

25. Sturm G, Lamina C, Zitt E, Lhotta K, Haider F, Neyer U, et al. Association of $\mathrm{HbA} 1 \mathrm{c}$ values with mortality and cardiovascular events in diabetic dialysis patients. The INVOR study and review of the literature. PLoS ONE[Internet]. 2011[cited 2016 Mar 18];6:1-8. Available from: http://journals.plos. org/plosone/article?id = 10.1371/journal. pone.0020093

26. Jiang $Y$, Osgood N, Lim H, Stang MR, Dyck R. Differential mortality and the excess burden of end-stage renal disease among First Nations people with diabetes mellitus: a competing-risks analysis. Can Med Assoc J[Internet]. 2014[cited 2016 Mar 18];186(2):103-9. Available from: https://www.ncbi.nlm.nih.gov/pmc/articles/PMC3903736/pdf/1860103.pdf

27. Wakasugi $M$, Narita I, Iseki K, Moriyama T, Yamagata $\mathrm{K}$, Tsuruya $\mathrm{K}$, Yoshida $\mathrm{H}$, et al. Weight gain after 20 years of age is associated with prevalence of chronic kidney disease. Clin Exp Nephrol[Internet]. 2012[cited 2016 Mar 18];16(2):259-68. Available from: http://link. springer.com/article/10.1007\%2Fs10157-011-0565-3

28. Wittwer I. Iron deficiency anaemia in chronic kidney disease. J Ren Care[Internet]. 2013[cited 2016 Mar 18];39(3):182-8. Available from: http://onlinelibrary.wiley.com/doi/10.1111/j.1755-6686.2013.12026.x/epdf

29. Khalil AA, Darawad M, Gamal EA, Hamdan-Mansour AM, Abed MA. Predictors of dietary and fluid non-adherence in Jordanian patients with end-stage renal disease receiving haemodialysis: a cross-sectional study. J Clin Nurs[Internet]. 2012[cited 2016 Mar 18];22:127-36. Available from: http://onlinelibrary.wiley.com/doi/10.1111/j.1 365-2702.2012.04117.x/epdf

30. Fülöp T, Pathak MB, Schmidt DW, Lengvárszky Z, Jun$\cos \mathrm{JP}$, Lebrun $\mathrm{CJ}$, et al. Volume-related weight gain and subsequent mortality in acute renal failure patients treated with continuous renal replacement therapy. ASAIO J[Internet]. 2010[cited 2016 Mar 18];56(4):3337. Available from: https://www.ncbi.nlm.nih.gov/pmc/ articles/PMC2895683/pdf/nihms-203512.pdf 